\title{
Comprehensive Income Options: A Detriment To Transparency
}

Brian D. Fitzpatrick, Rockhurst University, USA

Sudhakar S. Raju, Rockhurst University, USA

Anthony L. Tocco, Rockhurst University, USA

\begin{abstract}
The Financial Accounting Standards Board (FASB) in 1997 compromised its belief that comprehensive income (CI) should be listed either in a combined statement of net income and CI or in a separate statement of $C I$ and allowed corporations to choose using the statement of changes in stockholders' equity (SCSE). Of course, the latter option implies just as Jordan and Clark (2002) suggest, that CI is not a measure of financial performance. Studies incorporating professional analysts by Hirst and Hopkins (1998) and a study of nonprofessional investors by Maines and McDaniel (2000) both conclude that format presentation matters and behaviors can be affected. We believe that FASB should revisit the format structure of CI and eliminate the SCSE option, which was their initial intent before they compromised with corporate managers in 1997. In addition, we believe that all items of other comprehensive income (OCI) - foreign currency translation adjustment, pension value adjustments and adjustment to securities-for-sale should be presented on an after-tax basis only in order to prevent investors from being forced to comb through the footnotes.
\end{abstract}

Keywords: Comprehensive income, continuing income, derivatives, economic income, FASB, format presentation, pension liability adjustments, realized cash flow, SFAS 130, sustainable income, translation exposure

\section{INTRODUCTION}

0

omprehensive income, according to SFAS 130, is calculated by altering net income for dirty surplus items, which are called "other comprehensive income". Comprehensive income possesses four components: unrealized holding gains and/or losses that are created from changes in the fair market value of availablefor-sale securities, foreign currency translation gains and losses, increase or decrease in additional minimum pension liability, and unrealized holding gains or losses from derivative instruments (Wild, Subramanyam and Halsey 2004). A quick reference example would start with net income and then systematically record the other comprehensive income items as shown below:

Net Income

XXX

Example Other Comprehensive Income:

+ / - Unrealized holding gain or loss on marketable securities

+/ - Adjustments to Foreign Currency Translation

$\mathrm{XX}$

$+/$ - Pension Liability Adjustments

$\mathrm{XX}$

$+/$ - Unrealized gain or loss on derivatives

$\underline{\mathrm{XX}}$

Comprehensive Income

XXXX

(Wild, Subramanyam and Halsey, p.318). 
Usually, income statements report three alternative measures of accounting income: net income, comprehensive income, and continuing income. Although the bottom line is called net income, GAAP does allow many direct adjustments to equity to pass by the income statement - called "dirty surplus items". SFAS 130 allows comprehensive income in order to solve this problem. The implication is that comprehensive income is a proxy for economic income - usually measured as cash flow plus the change in the fair net asset value. An intermediate income component - called "continuing income" - is a measure which excludes extraordinary items, the effects of discontinued operations, and the cumulative effects of accounting changes. Continuing income may be listed as income before extraordinary items, income before discontinued operations, or income before cumulative effects of accounting changes. Core income is another item that excludes all nonrecurring items listed as separate line items on the income statements (Wild, Subramanyam and Halsey, 2004). Economic income is usually measured as cash flow plus the change in the fair value of net assets. Income includes realized (cash flow) and unrealized (holding gain or loss) components. Permanent income, which is also called "normalized" or "sustainable income", is the stable average income a company expects to earn over its life time (Wild, Subramanyam and Halsey, 2004).

Comprehensive income should encompass all changes in equity, except transactions from the owners. Comprehensive income will cover up to four changes in equity that are not presently belonging to net income: adjustments to foreign currency translations, net unrealized gains and losses on available-for-sale securities, pension costs which are unrealized, and deferred gains or losses from derivatives used for cash flow hedges. The two most common cash flow hedges are interest rate swaps designed to synthetically turn floating rate debt into fixed rate debt and futures contracts, which hedge forecasted sales (price changes could change the cash receipts of crude oil, natural gas, or some other arrangement) (Spiceland, Sepe and Tomassint 2004).

Comprehensive income created during the reporting period may be reported in three different venues: additional income statement section, a section in the statement of shareholders' equity, or a totally separate statement usually found in a disclosure note. Comprehensive income, which builds up over the current and prior time periods, will be reported as a distinct component of shareholders' equity. Accumulated other comprehensive income signifies the cumulative summation of changes in each component formulated during each reporting period throughout all prior years. (Spiceland, Sepe and Tomassint 2004)

\section{LITERATURE SUPPORT}

According to Pandit and Phillips (2004), SFAS 130 allows three formats for presenting other comprehensive income (OCI) and total comprehensive income (TCI):

1. Combined statement of net income and comprehensive income (below the line for net income in the traditional income statement)

2. Implement a separate comprehensive statement that begins with the amount of net income for the period

3. Use the statement of changes in stockholders' equity

Although FASB encourages the use of OCI and TCI components to utilize the first or second format, reporting entities follow their own desires. In fact, the original desire of FASB was to limit the corporations to just the first two options. The authors of this paper believe that FASB's initial thought process was correct and that FASB should eliminate the changes in stockholders' equity option. Pandit and Phillips (2004) examined the listing of comprehensive income in the financial statements to determine the mode of choice. They randomly collected a sample of 100 NYSE-listed companies, utilizing fiscal periods ending on or after December 31, 2002. Their research indicated that 89 percent of the studied companies implemented the third format (statement of changes in stockholder's equity). A meager 9 percent of the companies elected to implement an individual comprehensive statement, and just two percent of the database displayed comprehensive income as a component of their income statements.

Pandit and Phillips (2004) observe that entities possessing negative OCI were almost twice as likely to present it in the statement of changes in stockholders' equity, even though FASB prefers them to show OCI items either in the income statement or in a separate statement of comprehensive income. The authors of this manuscript believe that the second option - creating a separate statement of comprehensive income that begins with the amount 
of net income for the year - will create the greatest amount of accounting transparency. We are confused why FASB allows three different formats that simply allow for investor confusion. Interestingly, Maines and McDaniel (2000) found that less sophisticated investors are more prone to use comprehensive income information for corporate and management assessment if it is included in a separate statement of comprehensive income. Hirst and Hopkins (1998) also discovered that financial analysts are more prone to uncover evidence of earnings management on certain items only if they are presented in a separate statement of comprehensive income. We agree with Pandit and Phillips (2004) that more FASB guidance might be needed about the format for listing comprehensive income items. Since a separate statement is a FASB preference, why not make the format mandatory? Individual investors do not need to compare apples to oranges and the transparency goal would be better served. After all, the purpose of SFAS 130 was to list all comprehensive income items in a separate prominent financial statement (Pandit and Phillips 2004).

Pandit and Phillips (2004) observe that the bear market of 2000-2002 might have forced many companies to experience large unrealized losses on their investment portfolios (i.e., available-for-sale securities). If companies choose to use the third option of "hiding" other comprehensive income in the statement of changes in stockholders' equity, this will only serve to confuse the average investor. FASB is not allowing for maximum transparency by allowing companies the statement of changes in stockholders' equity option. In the Pandit and Phillips study (2004), only 31 companies out of 89 that incorporated the statement of changes in stockholders equity option, reported overall positive OCI, while the majority (58 companies) reported overall negative OCI. So, in spite of FASB's preference that OCI items be shown either in the income statement or in a separate statement of comprehensive income, corporations possessing negative OCI were almost twice as likely to present it in the statement of changes in stockholders' equity. It seems unfathomable that FASB released SFAS 130 ("Reporting of Comprehensive Income") effective for fiscal years beginning after December 15, 1997; they did not create a concerted movement to require a mandatory statement, even though FASB does not like the OCI items being "hidden" in the statement in stockholders' equity (Pandit and Phillips 2004).

As stated, FASB allows firms to list comprehensive income in a combined statement of net income and CI, in a separate CI statement, or in a statement of changes in stockholders' equity. In addition, items of other comprehensive income - unrealized gains and losses on available-for-sale securities, foreign currency translation adjustments and minimum pension liability adjustments - may be reported on either a before-tax or after-tax basis; but if the before tax option is implemented, then the tax effects must be disclosed in the footnotes. Once again, for the sake of transparency, FASB should just require the after-tax option. Why should the investor have to comb through footnotes. FASB, in a political capitulation, allowed the reporting in a statement of changes in stockholders' equity, even though they desired allowing just the first two options (i.e., in a combined statement of net income and $\mathrm{CI}$ and in a separate statement of CI). More effort should be made to protect the end-user of financial statements, not the corporate managers. The goal should be accounting transparency, not making corporations happy. As Jordan and Clark (2002) communicate, reporting CI in a statement of changes in stockholders' equity conveys to the users of financial statements that all of this is not connected to corporate performance, and thus, it is rarely used by investors. This belief is consistent with Maines and McDaniel (2000) who illustrated that nonprofessional investors will only use CI in management performance evaluation if it is presented in a separate CI statement. King and Reed (1999) and Hirst and Hopkins (1998) showed similar results, albeit their studies utilized professional investors.

Jordan and Clark (2002) concentrated their research on firms from only the financial service industry. Their decision was based on the assumption that most firms in the industry would report CI because of their holdings of available-for-sale securities, and their belief that Dhaliwal et al. (1999) was right when uncovering evidence that firms in this industry have their CI more strongly associated with returns or market value and that the $\mathrm{CI}$ is a better predictor of future cash flows than net income is. Moreover, Dhaliwal et al. (1999) found that the only item of OCI that improves the association between income and returns is the adjustment for available-for-sale securities. Obviously, the primary OCI item for financial service firms is the available-for-sale securities section.

Jordan and Clark (2002) collected data from 100 randomly financial service firms for 1998 (first year that CI requirement was implemented). Because they wanted to make an analysis of the company size and reporting format, they stipulated that all firms had to be publicly traded. They found that only 37 percent of their firms chose 
a performance-based reporting option - 12 percent used the combined statement of net income and CI, while 25 percent used the separate statement of CI - while 63 percent chose to use the statement of changes in stockholders' equity (the non-performance-based option).

Jordan and Clark (2002) also found that there is an association between the direction of total OCI for a financial-service firm and its choice of reporting format. They showed that firms with negative OCIs possess a greater propensity to report CI in a SCSE format than do firms possessing positive OCIs. Their study indicated that just 18.92 percent of the firms utilizing a performance-based financial statement experienced negative OCIs, while 46.03 percent of the firms choosing a nonperformance-based financial statement incurred negative OCIs.

Consistent with other research, Jordan and Clark (2002) concluded that reporting CI in a statement of changes in stockholders' equity (non-performance mode) will result in CI information receiving less weight, and it will ultimately be used less often by users when it is compared to reporting data within one of two performancebased financial statements. We believe that the waiting game for FASB should end and the statement of changes in stockholders' equity option should be eliminated, which was ironically the gut feeling of FASB back in 1997. In addition, we believe that all OCI items be reported on an after-tax basis. This will eliminate the need for the financial data user to comb through footnotes. After all, the goal of FASB should be to create the greatest amount of accounting transparency, which is why their initial wishes should now come to fruition.

Biddle and Choi (2003) found that disclosure of comprehensive income components is useful. They correctly point out that managers have consistently argued that they should not be held responsible for earnings components over which they have no control. Corporate managers, through intense lobbying, have been instrumental in passage of several FASB standards that explicitly introduce "dirty surplus" items to balance sheet owners' equity and, in essence, bypassing income acknowledgement. All of the other comprehensive items - as of 1998 - are a case in point: adjustments to unrealized gains and losses on available-for-sale marketable securities (SFAS 12 and 115, effective 1975 and 1993 respectively), adjustments to foreign currency translations (SFAS 8 and 52, effective 1976 and 1982 respectively), and minimum required pension liability adjustments (SFAS 87, effective 1986). The proponents of comprehensive income have made their counterpoints that "dirty surplus" exclusions will violate the articulation of the income statement and balance sheet and allow managers to manipulate earnings. The proponents have also had their successes with FASB and its predecessor, the Accounting Principles Board (APB). Their successes to move toward more comprehensive income measures include: APB Opinion 9 (effective 1966), Statement of Financial Accounting Concepts 5 (issued 1984), and, of course, SFAS 130 (effective 1997). Our argument is to allow FASB to enforce their original leanings by eliminating the statement of changes in stockholders' equity option, and if there are OCI items, that they be reported on an after-tax basis in order to prevent investors from searching through the footnotes.

Biddle and Choi (2003) used compustat data for firms in the 1994-1988 pre SFAS 130 implementation time era. They conclude that FASB chose wisely its definition of CI in SFAS 130. Among 16 different definitions of income, NI 130 (CI defined by FASB statement 130) exhibited the greatest information content. Comprehensive Income, defined by SFAS 130, is measured as follows: NI $130=$ net income + adjustment for unrealized holding gains/losses on marketable securities + adjustment for foreign currency translation + adjustment for pension liability. When they altered income/component sets, the rankings were altered, showing fully comprehensive income with the greatest amount of information content. Their study concluded two main themes: 1) that different definitions of income provide different decision usefulness utilizing different applications, which may be beneficial or detrimental to the investment community, and 2) more importantly, it is a decision useful to disclose separately comprehensive income components in order to create a greater transparency. Their research supports the FASB in SFAS 130 that it is better to disclose separately the components of comprehensive income as adjustments to net income. Choi and Das (2003) appear to use the same data base as Biddle and Choi (2003) and conclude that comprehensive income is associated with analysts "earnings forecast revisions and forecast errors." They state that the future recognition of unrecognized losses is more predictable than the future recognition of unrecognized gains. In their study, analysts revised their year $t+l$ 's forecast downward when comprehensive income was smaller than net income, but asymmetrically did not revise the forecast upward when comprehensive income was greater than net income. 
Barth, Trimbath, and Yago (2003) found that CFOs around the world considered financial statement disclosure and corporate corruption to be major corporate problems long before the Enron debacle in 2001. Their work showed results of a CFO survey conducted across 40 countries during the fall of 2000 and the spring of 2001. A large majority of the global respondents, including the USA, thought the lack of adequate disclosure of information by corporations to be a larger issue than either corrupt business practices or lack of effective accounting guidelines. This supports our recommendation to offer less guidelines for CI by eliminating the statement of changes in stockholders' equity and by reporting OCI items on an after-tax basis.

Barth, Trimbath and Yago (2003) confirmed that only in the United Kingdom did more CFOs think the lack of effective accounting guidelines to be the most pressing issue. Their results were quite educational. Shockingly, they found that in one-half of the countries, 26 percent or more of the CFOs publicly stated that they do not disclose the full extent of their company's risk-taking to investors. New Zealand (at 53 percent) and Norway (at 47 percent) were high, while the USA's percentage was just 15 percent. Also in one-half of the 40 countries, 29 percent or more of the CFOs indicated that their companies willingly do not disclose "forward looking information" - strategic goals, such as targets, plans and financial goals. France was the only major industrial country where more than 50 percent of the CFOs did not offer information about corporate planning. The figure for the USA was surprisingly high at 31 percent. This may explain why most companies choose the statement of changes in stockholders' equity option in order to keep the investor from looking too much into the CI issues. Eliminating this option should be useful to investors, even if, at the very least it eliminates the temptation not to individually break down the CI items. Surprisingly again, in one-half of the countries, 20 percent or more of the CFOs divulged that their companies do not even disclose information pertaining to major business units. Botswana ranked the highest at 58 percent, while France was at 43 percent, Norway at 47 percent, and the USA came in at 15 percent. Eliminating the SCSE option with CI will force a better breakdown for investors, which should create a greater transparency for the end-user.

Hirst and Hopkins (1998) argued that analysts' valuation judgments will be affected by the clarity of the comprehensive income disclosures. They had 96 analysts who participated in their study and found that clear income statement disclosure of comprehensive income enhances the transparency of a company's earnings management activities, and more importantly reduces analysts' valuation judgments to the same level for the firm that does not manage its earnings. Additionally, they found that the disclosure of $\mathrm{CI}$ in the statement of changes in shareholders' equity section allowed by SFAS No. 130 and adopted by the majority of US corporations, is not as effective as the income statement disclosure in outlining earnings management. Once again, this confirms the initial reluctance to allow the statement of changes in stockholders' equity. We agree with Hirst and Hopkins that analysts' valuation judgments can be affected by the clarity of the comprehensive income disclosure.

Brown (1997) showed that financial analysts regard the statement of changes in equity among the least useful components of the annual report - and as Hirst and Hopkins (1998) point out - since the statement is not a performance statement, reporting should be less effective than using the combined statement of net income and CI or the separate CI statement.

The Hirst and Hopkins (1998) experiment concentrates on the income statement display of comprehensive income and contrasts this with the SCSE. In addition, they uncover whether the company will engage in earnings management - either sold and repurchased or continued to hold available-for-sale marketable securities that experienced holding gains in prior periods, thus interpreting the clarity of CI requirements. Once again, they found results supporting their hypothesis that clear IS display of CI and its components does enhance transparency of a company's earnings management activities. Their results also support the notion that reporting CI and its components in the SCSE is not as effective as the IS display in revealing earnings management and in reducing analysts' stock price judgments. They found that buy-side analysts valued the earnings management (EM) firm significantly higher than the no earnings management (NEM) firm.

Many behavioral studies support the Hirst and Hopkins (1998) research. Johnson, Payne and Bettman (1988) discovered that presentation of an uncertain outcome in a hard-to-process fractional format (e.g., $\frac{536}{670}$ ) 
causes more preference reversals than presentation of uncertain outcomes in an easier-to-process decimal format (e.g., .8). Sanbonmatsu et al. (1997) state that the direct presentation of decision-relevant information increases the chances it actually will be used, and Russo(1977) shows that explicitly summarizing information that is already accessible can increase the use of the information and can affect behavior. Russo (1977) brilliantly shows how a drastic shift to inexpensive grocery products took place when per-unit price information was posted. Keep in mind that the available information was there for the consumer to calculate, but the change in consumer behavior did not come to fruition until the unit price was clearly shown. Russo states that "it is not sufficient that the information be available; it must also be processable." (p. 194) Many corporate managers argue that we have all the information we need in the statement of changes in stockholders' equity, but like Russo's grocery study, Hirst and Hopkins show that the clarity of the IS use of CI gives the analyst the clarity needed to make decisions. We believe that FASB should have followed their initial reservations about the SCSE option and disallowed it. It is time to eliminate the option.

It is interesting to note that Hirst and Hopkins (1998) conducted a $3 X 2$ between-subjects experiment using 96 buy-side equity security analysts and portfolio managers. The participants averaged 14 years experience and 82 percent were Certified Financial Analysts (CFAs). They excluded professionals who specialized in banking, insurance or other financial industries because the company included in their experiment was an industrial firm. Professionals were much more likely to indicate that CI was reported in the CI income statement conditions (94 percent) than in the no CI conditions. Only 50 percent of the participants under the SCSE format indicated that CI had even been reported. Consistent with Brown (1997), this shows that information relegated to the SCSE will not be as widely implemented as information tied to the IS format of CI.

Maines and McDaniel (2000) used non-professionals in their study, but like Hirst and Hopkins (2000) conclude, there are valid reasons for being specific with comprehensive income. They examined how nonprofessional investors' processing of comprehensive income is affected by alternative presentation formats; they utilized information disclosing the volatility of unrealized gains on available-for-sale marketable securities. They conclude that investors' judgments of corporate and management performance reflect the volatility of comprehensive income only when the presentation is in the statement of comprehensive income. Consistent with behavioral studies, the findings show that format affects how non-professional investors weight comprehensive information, not whether the investors procure this data or how they choose to evaluate it.

Like Hirst and Hopkins (2000), Maines and McDaniel (2000) found the SCSE was not useful. They state that corporate managers, in comment letters to the FASB, believed that non-professionals would be more influenced by the presentation format of CI than would be professional analysts. It is time for FASB to revisit the issue, as promised, and take away the SCSE option in dealing with CI.

Maines and McDaniel (2000) took 95 evening MBA students and had them analyze an insurance company's financial statements, which presented unrealized gains on investments in either a SFAS No. 130 statement of CI or one of two statements of stockholders' equity formats: the first using SFAS No. 130 and the later based on the prior standard, which was SFAS No. 115 (FASB 1993). They used a 3 (format) by 2 (volatility) between-subjects design in trying to determine whether investors' judgments differ between SFAS No. 130 and SFAS No. 115 presentations, as well as between both SFAS No. 130 formats. Again, their results show that nonprofessional investors rely on financial statements to alert them to the nature and importance of comprehensive income information. They discovered that only the statement of comprehensive income provided additional benefits beyond those of SFAS No. 115. They question FASB's decision to allow companies a choice between financial statement formats and, like us, believe that the choice will probably not achieve the exposure draft's original objectives of enhanced visibility and increased use of comprehensive income information for a significant group of users. It is important to note that participants in the Maines and McDaniel study had no professional investment experience. Three insurance companies were implemented (Allstate, Chubb and Nationwide) and statistics from Petroni and Wahlen (1995) were used as the foundation for the company's financial statements. We join all of these diligent researchers and, again, ask FASB to eliminate the SCSE option. 


\section{CONCLUSION}

We believe that the Financial Accounting Standards Board (FASB) compromised its belief in 1997 that comprehensive income (CI) should be listed either in a combined statement of net income and CI, or in a separate statement of CI when they allowed corporations to choose using the statement of changes in stockholders' equity (SCSE). The waiting game for FASB should end and the statement of changes in stockholders' equity option should be terminated, which was ironically the gut feeling of FASB back in 1997.

Studies incorporating professional analysts by Hirst and Hopkins (1998) and a study of nonprofessional investors by Maines and McDaniel (2000) both conclude that format presentation matters and human behaviors can and are affected.

In addition, we propose that all other comprehensive items (OCI) be reported on an after-tax basis. This should eliminate the need for the financial data user to comb through footnotes. The ultimate goal of FASB should be to create the greatest amount of accounting transparency; their initial wishes should now come to fruition.

\section{AUTHOR INFORMATION}

Brian D. Fitzpatrick is a professor of finance for the Helzberg School of Management at Rockhurst University in Kansas City, Missouri. He earned his Ph.D. in Finance with a concentration in Investments from Saint Louis University. Dr. Fitzpatrick spent ten years in the Investment field including positions with two major Wall Street wire houses, as well as serving as senior vice president for both Financial Corporation of America and Commerce Bancshares. Brian has won the Rockhurst University's Teaching Excellence Award, and he has published in nine different fields.

Sudhakar Raju is Professor of Finance at Rockhurst University in Kansas City, Missouri. He teaches graduate courses in Corporate Finance, Financial Policy and Derivatives Markets. He has served as a consultant to several organizations including: the World Bank, the United Nations Development Program (UNDP) and the Chicago Board of Trade.

Anthony L. Tocco is a professor of Accounting, earning his doctorate in accounting and finance from Saint Louis University. He has consulted with more than 300 businesses and individuals in the accounting and finance areas. As an entrepreneur, Dr. Tocco has owned and operated his own businesses. He also serves on two boards of directors for Kansas City companies and as chairman of the board for a not-for-profit organization. He is a past George and Gladys Miller Chair in Business Administration at Rockhurst University and has authored numerous articles in accounting and broader business areas.

\section{REFERENCES}

1. Barth, James R., Trimbath, Susanne and Yago, Glenn. 2003. "Before the Enron Collapse: What Corporate CFOs Around the World said About the Status of Accounting and Disclosure Practices." Review of Pacific Basin Financial Markets and Policies, Vo. 6, No. 4, pp433-440.

2. Biddle, Gary and Choi, Jong-Hag. 2003. "Is Comprehensive Income Useful?" Working Paper from the Columbia University Burton Workshop and Summer Symposium on Accounting Research. Authors are associated with the Hong Kong University of Science and Technology. Draft, March 2, 2003, pp. 1-36.

3. Brown, P.R. 1997. "Financial Data and Decision Making by Sell-Side Analysts." The Journal of Financial Statement Analysis. Spring, No. 2. pp43-48.

4. Choi, Jong-Hag and Das, Somnath. 2003. "The Predictive Ability of Comprehensive Income Disclosures Under SFAS No. 130." Working Paper. Jong-Hag Choi is associated with the Hong Kong University of Science and Technology, and Somnath Das is associated with the University of Illinois-Chicago. Oct. 2003. pp. 1-34.

5. Dhaliwal, D.; Subramanyaman, K.E. and Tresevant, R. 1999. "Is Comprehensive Income Superior to Net Income as a Measure of Firm Performance?” Journal of Accounting and Economics January Vol. 26: 4367. 
6. Financial Accounting Standards Board. 1985. "Elements of Financial Statements.” Statement of Financial Accounting Concepts. Stamford, CT: FASB. Number 6.

7. Financial Accounting Standard Board. 1997. "Reporting Comprehensive Income." Statement of Financial Accounting Standards. Stamford, CT: FASB. Number 130.

8. Hirst, D.E. and Hopkins, P.E. 1998. "Comprehensive Income Reporting and Analysts' Valuation Judgments" Journal of Accounting Research. Vol. 36: (Supplement) 47-75.

9. Johnson, E.J. Payne, J. W. and Bettman, J.R. 1988. "Information Displays and Preference Reversals." 1988. Organizational Behavior and Human Decision Processes. August, pp. 1-21.

10. Jordan, Charles E. and Clark, Stanley. 2002. "Comprehensive Income: How Is It Being Reported and What are Its Effects." The Journal of Applied Business Research Vol. 18, No. 2.

11. King, T.E., Ortegren, A.K., and Reed, B.J. 1999 "An Analysis of the Impact of Alternative Financial Statement Presentations of Comprehensive Income.” Academy of Accounting and Financial Studies Journal. Vol. 3, No. 1, pp. 19-42.

12. Maines, L.A. and McDaniel, L.S. 2000. "Effects of Comprehensive Income Characteristics on Nonprofessional Investors' Judgments: the Role of Financial Statement Presentation Format." Accounting Review Vol. 75, No. 2: 179-208.

13. Pandit, Ganesh and Phillips, Jeffrey J. 2004. “Comprehensive Income: Reporting Preferences of Public Companies.” The CPA Journal November, Vol. 74, No. II. p. 40.

14. Petroni, K.R. and Wahlen, J.M. 1995. "Fair values of Equity and Debt Securities and Share Prices of Property - Liability Insurers.” The Journal of Risk and Insurance. December, No. 62, pp. 719-737.

15. Russo, J. 1977. "The Value of Unit Price Information." 1977. The Journal of Marketing Research. May, No. 14, pp. 193-201.

16. Sanbonmatsu, D.M., Kardes, F.R., Posavac, S.S. and Houghton, D.C. 1997. "Contextual Influences on Judgment Based on Limited Information.” Organizational Behavior and Human Decision Processes. March, pp. 251-264.

17. Spiceland, David; Sepe, James and Tomassini, Lawrence A. 2004.Intermediate Accounting Updated Third Edition. McGraw-Hill Irwin Inc.

18. Wild, John J.; Subramanyam, K.R. and Halsey, Robert F. 2004. Financial Statement Analysis. Eighth Edition. McGraw-Hill Irwin, Inc. 